\title{
The Effects of Money Illusion on Consumer Perception: The Euro Changeover
}

\author{
Tommy Hsu \\ Tarleton State University
}

The notion of money illusion is an economic phenomenon which has been recognized for a long time. A review of literature shows that at least two different types of money illusion have been covered and discussed by former researchers. One of them refers to a tendency to think in terms of nominal rather than real monetary values. This definition focuses on the time value of money. Most of consumers tend to ignore the time value of their money and just look at what they have in terms of nominal values. Another type of money illusion that has been researched is the nominal value (or called "face value") of money (currency). It has been found to affect consumers' perception of real money when they conduct purchases. In this preliminary research, both of these two types of money illusion are discussed and four research propositions are stated.

Keywords: money illusion, euro illusion, time value of money, perceived value of money

\section{INTRODUCTION}

Even though the recognition of money illusion has already had a long history, it seems that most economists are still struggling to have mixed feelings regarding if money illusion should be presented when they are testing their models. In Howitt's (1987) entry on money illusion in the New Palgrave Dictionary of Economics (1987, Vol 3, pp 518-519)

"The absence of money illusion is the main assumption underlying the long-run neutrality proposition of the quantity theory of money. But the presence of money illusion has also frequently been invoked to account for the short-run non-neutrality of money, sometimes by quantity theorists themselves, as in the case of Fisher. On the other hand, many monetary economists have reacted adversely to explanations based on such illusions, partly because illusions contradict the maximizing paradigm of microeconomic theory and partly because invoking money illusion is often too simplistic an explanation of phenomena that do not fit well into the standard equilibrium mold of economics. Behavior that seems irrational in a general equilibrium framework may actually be a rational response to systemic coordination problems that are assumed away in that framework."

Besides that, Larsen (1989) also noted in his article of Money Illusion and Residential Real Estate Transfer that "those who hold the rational expectations view assert that economic behavior is based on real rather than nominal values. Such rational behavior is possible only if the market participants are free of 
money illusion". Therefore, we can see that it is barely possible to ignore the presence of money illusion in the market.

Recent research also shows that money illusion not only just presents in the market, but also plays a more and more important role influencing the market and participants. For example, in the stock market, Cohen, Polk \& Vuolteenaho (2005) mentioned that "stock market investors may also suffer from a particular form of money illusion, incorrectly discounting real cash flows with nominal discount rates". Another example was presented by Brunnermeier \& Julliard (2008) in terms of housing markets that "a reduction in inflation can fuel run-ups in housing prices if people suffer from money illusion". They also further illustrated that "investors who decide whether to rent or buy a house by simply comparing monthly rent and mortgage payments do not take into account the fact that inflation lowers future real mortgage costs" (Brunnermeier \& Julliard, 2008).

On the other hand, recent research also mentioned another type of money illusion that indicates people may suffer from money illusion when they are using money with different face values, like a foreign currency. Przybyszewski \& Tyszka (2007) stated that "money cannot be reduced to its economic concept as a medium of exchange of goods and services. Instead, money for many people has different moral and emotional meanings". In this case, the best example would be the Euro case. After many European countries began to use Euro as their major currency, people in these countries suffered from money illusion and their behaviors were affected as well.

\section{WHY DOES MONEY ILLUSION MATTER?}

Although money illusion has been recognized for decades, some economists still prefer to ignore its presence because they think it would not help them to find the market equilibrium. So, the question here becomes "why does money illusion matter?" To further answer this question, two separate questions should be addressed: "why does the illusion on time value of money matter?" and "why does the illusion on the perceived value of money matter?".

\section{Illusion on Time Value of Money}

"Since the absence of money illusion means that an individual's preferences, perceptions and, hence, choices of real magnitudes are not affected by purely nominal changes, it is natural to view money illusion as a framing or representation effect" (Fehr \& Tyran, 2001). Although more and more people have realized the money they have right now will have different value from that they will have in ten years, Fehr \& Tyran (2001) still thought that "it is important to note that the nominal representation of an economic situation is probably the natural representation for most people". "Therefore, it is likely that people often perceive and think about economic problems in nominal terms which may induce money illusion" (Fehr \& Tyran, 2001).

In addition, Kane \& Klevorick (1967) also mentioned that "someone suffering from money illusion regards his stock of nominal assets as convertible into potential more or less real goods and services than market prices actually allow". When this kind of situation happens, those individual irrational behaviors will significantly affect the entire market. Therefore, Fehr \& Tyran (2001) concluded in their research that "a small amount of individual-level money illusion may cause considerable aggregate nominal inertia after a negative nominal shock".

For so many years, "money illusion has been considered as largely irrelevant for the nominal inertia" (Fehr \& Tyran, 2001). However, Fehr \& Tyran (2001) found out that even in the absence of other factors, such as informational frictions, costs of price adjustment, and staggered contracts, a fully anticipated negative nominal shock can cause long-lasting nominal inertia that is associated with large real income losses caused by money illusion. Therefore, money illusion in this sense not only matters but also plays an important role in economic activities. 


\section{Illusion on Perceived Value of Money}

In the recent decade, with the progress of globalization and the popularity of Internet shopping, people now have more opportunities to experience doing business or consuming goods with foreign currencies. Facing different face values of money, consumers tend to respond to them more emotionally than rationally. Besides that, Przybyszewski \& Tyszka (2007) also found out that "a high level of seeing money as the source of power and prestige, being afraid of losing power and prestige together with losing money, and the anxiety related to money issues, were associated with a lower level of ability to cope with emotions and with emotional instability".

People who have money with bigger face values tend to feel they become richer, and vice versa. For example, if one good costs 3,500 Taiwanese dollars or 100 US dollars (at the rate of 35:1), people buying it with US dollars tend to feel cheaper than those with Taiwanese dollars simply because the nominal value of money is lower. This illusion is caused by people's perceived value of money. These individual emotional behaviors may not seem significant to the entire market. However, with the increase of international business and the implementation of Euro, this issue has begun to draw attentions from economists.

\section{THE EURO CHANGEOVER}

In 1999, 12 European countries agreed to initiate the unity currency to replace the old currencies which they were using at that time. Therefore, "the Euro 2002 Information Campaign, conducted by the Eurosystem (the European Central Bank and the national central banks of the euro area) made the introduction of the Euro notes and coins on the first day of 2002 a largely expected event of which nearly all people were fully aware" (Cannon \& Cipriani, 2006).

At present, there are 27 countries in the EU, many of which will join the Euro in the future. Millions and millions of consumers in Europe will experience the shift to the Euro. The switch to the Euro raises a unique opportunity to study the effects of the new currency on people's daily life ranging from political and social aspects to psychological and cognitive factors (Marques, 1999).

The Euro changeover certainly brings in many research opportunities in marketing, especially in consumer behaviors and price perceptions. Zollinger (2002) has mentioned how people tend to depend on the scale of values they are familiar with when evaluating prices in Euros. It also indicates that customers' purchasing behaviors will continuously be affected by the illusion until they get used to the presences of both the Euros and their old currencies. On the other hand, another research area not to be studied further is about the influence of the currency changeover on the different stages of the consumer decision process (Desmet, 2002).

Over time, the Euro changeover will most likely benefit consumers (Mussweiler \& Strack, 2004). The opportunity to make price comparisons in a unitary currency should strengthen the possibility of lowering the prices of consumer goods across the countries which have joined and used the Euro.

\section{THE EURO ILLUSION}

After 12 European countries began to adapt the euro as their major currency, "a significant phenomenon related to the influence of nominal values on price recognition after the transition to the euro is the so-called euro illusion" (Missier, Bonini \& Ranyard, 2007). Therefore, "the euro illusion is a transient phenomenon that consists of currency-related asymmetries in the intuitive judgment of product prices made by consumers" (Missier, Bonini \& Ranyard, 2007). "In this case, the illusion stems from the fact that the prolonged experience with the former currency affects judgments and decisions involving prices expressed in the newly introduced currency" (Missier, Bonini \& Ranyard, 2007).

For example, the former Spanish Minister of Economy, Pedro Solbe, once mentioned in one conference that he usually saw many Spanish people left $€ 1$ on tables for tips after consuming just one cup of coffee. However, one cup of coffee cost about $€ 2$ which means that people overpaid for tips because they thought it was only "one" euro. One euro is about equal to 166 peseta. Therefore, from this case, it clearly illustrated 
how euro illusion affected consumers' behaviors. When consumers are facing different currencies, even though they have already known what current exchange rates are, it is difficult for them not to be affected by money illusion or, say, the emotion about their national currencies.

In research of Przybyszewski \& Tyszka (2007), they point out that "support vs. opposition to the common euro currency does not come from the perceived economic personal benefits, but originates from national or European feelings". They also further mention that "national feelings vs. European identity were correlated with the individual's attitudes towards the new euro currency. Economic factors were definitely less significant or almost completely insignificant" (Przybyszewski \& Tyszka, 2007). People in those 12 European countries have been using their own national currencies for lives. It is easier for them to process labeled prices in former national currencies and automatically affected by euro illusion. For instance, "when people experience higher prices in one currency than in another, the label of the former currency may inadvertently pass on the information 'expensive currency'. In such case, prices expressed in this currency can be perceived as more expensive than prices in another currency" (Przybyszewski \& Tyszka, 2007).

In addition, "for most countries, the transition to the euro led to a lower nominal value currency" (Gamble, 2007). Also, "in most countries prices and salaries seem smaller when expressed in euros than in the old domestic currency" (Gamble, 2007). Therefore, "this may cause people to feel poorer when they compare their salaries in euros to these in the old currency" (Gamble, 2007). Just like the example I mention earlier about Spanish people, "they may think that prices of consumer products expressed in euros are lower compared to the same prices expressed in the old currency" (Gamble, 2007).

Thus, even though information about the exchange rate can be easily obtained, "when consumers have difficulties, they may resort to conversion strategies (if these are relatively effortless), updating and re-activating the reference prices in the old currency" (Missier, Bonini \& Ranyard, 2007). Besides that, Missier, Bonini \& Ranyard (2007) further mention that the euro illusion appears to be very long lasting phenomenon. "The euro illusion can be one of the causes that make the appraisal of the real value of money very difficult, leading to a failure to notice significant price increases, and promoting annoyance" (Missier, Bonini \& Ranyard, 2007).

\section{Implications for Consumer Policy}

Although the euro has been implemented for years, "the transition to the euro has not been smooth and the attitude toward the currency is not very positive in many of the Eurozone countries" (Gamble, 2007). Gamble (2007) also demonstrates that "citizens remain confused about the new currency and feel anxious about being deceived as consumers". However, euro illusion may also provide those European governments some implications for policy implementation. "It appears particularly important to implement effective public policies to foster the process of adaption after a currency changeover" (Missier, Bonini \& Ranyard, 2007). In order to eliminate or at least minimize the effects of euro illusion, Gamble (2007) provides a good possible solution that "a more adequate solution seems to be dual pricing. Dual pricing forces retailers to provide prices in both the old currency and in the euro". On the other hand, "these policies can be very helpful in the case of countries that are going to join the euro in the coming years, especially when the exchange rate is steep and there are reasons to believe that consumers will have difficulties in making sense of novel prices" (Missier, Bonini \& Ranyard, 2007).

\section{MONEY ILLUSION IN CONSUMER BEHAVIOR}

Just like price discounts can positively affect consumers' purchasing behaviors, when consumers experience price raises, they will choose to buy less. On the other hand, when they find prices to drop, they will tend to buy more. Therefore, the idea of the Euro changeover is just like discounts or price rises.

For example, when US tourists travel to Japan and try to purchase something there. They will find out the nominal prices for every product are much higher than those priced in US dollars. Even though 
the products seem to price equally by taking exchange rates into account, the tourists may still tend to buy less. On the other hand, when US tourists travel to European countries which are using the Euro now, they will see the nominal prices for products are lower and tend to purchase more.

Obviously, the consumer behaviors are significantly affected by those nominal illusions. Purchasing goods for many consumers is an emotional process rather than a rational one. Thus, that's why consumers usually tend to ignore the real prices and only focus on the nominal prices. In this sense, Euro illusion, or say money illusion in general, can essentially influence consumers' behaviors.

\section{EURO ILLUSION IN PRICE PERCEPTION - REFERENCE PRICE EFFECT}

The concept of a reference price can be defined as the price against which buyers compare the listed price of a product or service (Monroe, 1990). Also, the reference price can be used by consumers to be the basis to evaluate whether the price is too high or too low. For example, when people from other countries visit the United States and try to make a purchase, they usually use their home currencies to be the reference prices to determine if the product priced in the US dollar is expensive or not. In other words, when customers are unfamiliar with the price tagged by foreign currencies, they tend to translate them back into their home currencies and make the similar product priced in their home currencies the reference price to determine whether the product or service is priced reasonably.

Some researchers suggest that the reference price is a weighted average or a mode of the prices from the relevant category (Monroe, 1990). Furthermore, "the reference price does not seem to be a specific price, but rather a price acceptability zone" (Anttila, 2004). It is a price range that the consumer thinks to seem to be reasonable and acceptable.

\section{RESEARCH PROPOSITIONS}

Proposition 1: The Euro changeover positively affects the consumer's price perception if the nominal value of old currency is smaller than the Euro.

If the nominal value of the consumer's old currency is smaller than the Euro, which means that the product is priced in the Euro will be cheaper than that priced in the old currency, the consumer will tend to buy more products. For example, the nominal value of Italian Lire is much smaller than the Euro. When Italian consumers go to buy some products priced in the Euro, they will find out that the nominal price is way much smaller, which they may feel the products are "cheaper". Since they think the products are cheaper, they may tend to purchase more than how many they used to buy. Therefore, the Euro changeover positively affects the consumer's price perception if the nominal value of old currency is smaller than the Euro.

Proposition 2: The Euro changeover negatively affects the consumer's price perception if the nominal value of old currency is greater than the Euro.

If the nominal value of the consumer's old currency is greater than the Euro, which means that the product is priced in the Euro will be more expensive than that priced in the old currency, the consumer will tend to buy less products. For example, the nominal value of Irish Pound is slightly more than the Euro. When Irish consumers go to buy some products priced in the Euro, they will find out that the nominal price is a little bit higher, which they may feel the products are "more expensive". Since they think the products are priced higher, they may tend to purchase less than how many they used to buy. Thus, the Euro changeover negatively affects the consumer's price perception if the nominal value of old currency is greater than the Euro.

Proposition 3: The reference price effect negatively moderates the relationship between the Euro changeover and the consumer's price perception if the exchange rate is steep. 
If the exchange rate between the Euro and the old currency is steep, that means the consumers will experience a huge difference in price changes. This huge difference may negatively affect their purchasing behaviors. For example, since the exchange rate between the Euro and the Italian Lira is very steep, this doesn't help Italian consumers to get used to using the Euro quickly. There is a big price difference that Italian consumers are going to experience. Therefore, the reference price effect negatively moderates the relationship between the Euro changeover and the consumer's price perception if the exchange rate is steep.

Proposition 4: The reference price effect positively moderates the relationship between the Euro changeover and the consumer's price perception if the exchange rate is flat.

If the exchange rate between the Euro and the old currency is flat, that means the consumers will experience a relatively small difference in price changes. This small difference may positively affect their purchasing behaviors. For example, since the exchange rate between the Euro and the Irish Pound is very flat, this does help Irish consumers to get used to using the Euro quickly. There is only small price difference that Irish consumers are going to experience. Therefore, the reference price effect positively moderates the relationship between the Euro changeover and the consumer's price perception if the exchange rate is flat.

\section{TIME VALUE OF MONEY}

Even though the notion of money illusion, in terms of time value of money, has been recognized and studied for several decades, research shows that many important topics regarding money illusion began to be focused and studied just for as long as a decade. Among those different areas, stock markets and real estate markets are the fields that have been studied most and significantly.

\section{The Stock Market vs. Money Illusion}

Does the stock market also suffer from money illusion? Cohen, Polk \& Vuolteenaho (2005) noted that "when the difference between real and nominal quantities is small and stakes are relatively low, equating the nominal dollar amounts with real values provides a convenient and effective rule of thumb. Therefore, it seems plausible that people often ignore the rate of inflation in processing information for relatively small decisions". Investors tend to only focus on nominal market prices of shares rather than calculate real prices by taking inflation rate into account when evaluating financial information and making financial decisions. However, those small decisions from every investor could make significant contributions to the entire stock market.

Another implication from money illusion in the stock market is that "time variation in the level of inflation causes the market's subjective expectation of the future equity premium to deviate systematically from rational expectation" (Cohen, Polk \& Vuolteenaho, 2005). In the research of Cohen, Polk \& Vuolteenaho (2005), "recent time-series evidence suggests that the stock market does suffer from money illusion". For example, in the capital asset pricing model (CAPM), "a stock's beta with market is its sole relevant risk measure" (Cohen, Polk \& Vuolteenaho, 2005). Without the presence of money illusion, "the CAPM predicts that the risk compensation for one unit of beta among stocks, which is also called the slope of the security market line, is always equal to the rationally expected premium of the market portfolio of stocks over short-term bills" (Cohen, Polk \& Vuolteenaho, 2005).

However, if money illusion is considered when investors use the CAPM model to make predictions, the compensation for one unit of beta among stocks is larger than the rationally expected equity premium when inflation is low or negative (Cohen, Polk \& Vuolteenaho, 2005). On the other hand, this situation seems only to apply to the stock market. In the bond market, it is a different story. "Since nominal bonds have cash flows that are constant in those terms, estimating a growth rate for bonds is not difficult. In contrast, the task of estimating the long-term expected cash flow growth for stocks is 
far from trivial (Cohen, Polk \& Vuolteenaho, 2005). In this case, the bond market investors do not suffer from money illusion.

\section{Real Estate and Housing Markets vs. Money Illusion}

As I have mentioned earlier in this article, the housing market also significantly suffers from money illusion. The nominal rental and nominal mortgage payments are usually the only things for people to consider and compare when they are pondering whether to buy a house or rent an apartment. Similar to this, Brunnermeier \& Julliard (2008) also find that "inflation and nominal interest rate explain a large share of the time series variation of the mispricing, and that tilt effect is very unlikely to rationalize this finding".

Money illusion regarding the housing market may be defined as "the inability to properly distinguish changes in nominal values due to changes in real fundamentals from changes merely due to inflation" (Brunnermeier \& Julliard, 2008). For example, assume a person who suffered from money illusion bought a house for $\$ 100,000$ two years ago. He is selling his house now for $\$ 110,000$. If he does find a buyer and sells it for $\$ 110,000$, he will think that he just make a profit of $\$ 10,000$ without taking the interest rate or inflation rate into account. However, there is a possibility that he actually suffers from a loss from this transaction. "Market participants subject to money illusion think themselves better off than they really are simply because they have more money, ignoring the fact that price levels have increased so as to erode their purchasing or selling power" Larsen (1989).

Furthermore, Brunnermeier \& Julliard (2008) also note that "a reduction in inflation can generate substantial increases in housing prices in a setting in which agents are prone to money illusion". In addition, "people wrongly attribute a decrease in inflation to a decline in the real interest rate and consequently underestimate the real cost of future mortgage payments. Therefore, they cause an upward pressure on housing prices when inflation declines" (Brunnermeier \& Julliard, 2008). This is why every individual whose behaviors are affected by money illusion can significantly influence the entire market to move in a wrong direction. Here the housing market is the perfect example to show again why and how money illusion matters.

\section{MONEY ILLUSION AND NATIONAL CULTURE}

In order to further address the possible reasons that cause money illusion across countries, I would like to propose a possible relationship between national culture and money illusion. Although money illusion has generally affected consumers universally, there are still differences in degrees of affection. I believe national culture could be the potential factor that causes the degree differences. First of all, I will introduce the idea of national culture below.

The definition of culture has been developed in many ways. Based on Kluckhohn (1951), "culture consists in patterned ways of thinking, feeling and reacting, acquired and transmitted mainly by symbols, constituting the distinctive achievements of human groups, including their embodiments in artifacts; the essential core of culture consists of traditional ideas and especially their attached values". On the other hand, Kroeber and Parsons (1958) define culture as "transmitted and created content and patterns of values, ideas, and other symbolic-meaningful systems as factors in the shaping of human behavior and the artifacts through behavior".

Furthermore, cultures in different nations are even more significantly distinctive. Typically, national culture will have much more impact on employees than organizational culture does. Different organizations have different cultures so different nations have different cultures too. Clark (1990) has defined national culture as the attitude and thoughts commonly shared by people in the same nation. It regulates people's behaviors and affects their views towards the world. The most popular definition of national culture is the one created by Hofstede (1983). He provides four dimensions to identify culture relativity. These dimensions are power distance, uncertainty avoidance, individualism-collectivism and masculinityfemininity. Those four dimensions are commonly utilized by researchers to demonstrate differences in national cultures. 


\section{Power Distance}

Power can be viewed as a perception and a psychological representation of the strength of one's position in negotiation (Brett, 2000). Power distance is the degree of equality or inequality between members from one organization or country (Hofestede, 2005). There is always inequality existing in the society. According to Hofstede (1983), bosses tend to increase the power distance between their employees and them while employees are trying to decrease it.

Inequality can occur in areas such as prestige, wealth, and power. Different societies put different weights on status consistency among these areas (Hofstede, 2001). The country-level correlation of the preferred kind of decision making in the superior with the perception of the behavior of both superior and colleagues shows a fundamental fact about power distance in a hierarchy so that a society's way of dealing with power relationships is established through the values of superiors as well as of subordinates (Hofstede, 1983).

In addition, Hofstede (1991) also indicates that companies in high power distance countries such as Egypt, India, Malaysia, Nigeria, Saudi Arabia, and Venezuela tend to be more centralized and have less employee participation in decision-making. On the other hand, when superiors maintain less power distance, subordinates tend to prefer the consultative decision type, which can also be explained as an interdependence of superiors and subordinates. People from countries with lower power distances, such as the US, Sweden, Israel, Ireland, Germany, Denmark, Canada, and Austria, may have more freedom to express their own thoughts.

\section{Uncertainty Avoidance}

Uncertainty avoidance means the degree to which the members of a society feel uncomfortable with uncertainty and ambiguity, which leads them to support beliefs promising certainty and to maintain institutions protecting conformity (Hofstede, 1983). People in different societies tend to respond differently to the natural uncertainty. In countries where uncertainty avoidance is high, people have lower ambitions and prefer larger companies to work for. They also tend to avoid competition, resist changes, and don't like working for foreign managers. Hofstede (1983) also finds that there is no significant difference in uncertainty avoidance between male and female.

Besides that, when situations are unstructured, unclear, or unpredictable, individuals from societies with high uncertainty avoidance like Argentina, Spain, Peru, Mexico, Korea, Japan, Belgium, Chile, Greece, Egypt, and France would provide socially acceptable responses that are condoned by most people and to reduce personal risks (Hofstede, 1991). On the contrary, people from nations with low uncertainty avoidance, such as the US, Sweden, Canada, Denmark, India, Hong Kong, and England, might be more reflective and relatively broader-minded, which results in fewer needs for social approval and increased openness in intercultural communication which leads to additional risk taking, tolerance toward deviant behavior, and acceptance of innovative ideas (Hofstede, 1991).

\section{Individualism Versus Collectivism}

Individualism means the relative importance in a country of personal time, freedom, and challenge and the relative unimportance of training, use of skills, physical conditions, and benefits (Hofstede, 1983). Hofstede (1983) thinks that in a society with low individualism people will extend their loyalty from families to the organizations they work for. The typical example for this type of societies is Japan. That's why individualism and collectivism should be seriously considered when doing business with Japanese companies.

\section{Masculinity Versus Femininity}

Masculinity is the extent to which the dominant values in a society are male oriented, whereas the female's status is higher in a femininity culture. This dimension refers to the distribution of roles between the genders which is another fundamental issue for any society to which a range of solutions are found (Hofstede, 2001). Masculinity indicates the relative importance in the country of earnings, recognition, advancement, and challenge and the unimportance of the relations with managers, 
cooperation, desirable areas, and employment security (Hofstede, 1983). Therefore, Hofstede (1983) also thinks there are differences in work objectives between male and female employees.

With the understanding of national culture, we can be able to further understand how national culture is related to the notion of money illusion. For example, in the country with high uncertainty avoidance, since people tend to avoid uncertainties, they will not quickly adapt to using the new currency. In other words, they may be those consumers who are more affected by money illusion. Besides that, in the country in which collectivism is valued, people are more group-oriented and can be more efficient with working with others. Therefore, under this sense, consumers may tend to share information more with each other. This unique behavior may reduce the effect of the money illusion.

\section{CONCLUSION}

The notion of money illusion has been recognized, realized, and studied for decades. However, there had not been a significant amount of research about this topic until the recent decade. With the increasing cases showing that money illusion has been playing an important and critical role in many markets, this term, money illusion, is noticed and studied again.

As mentioned in this article, both two types of money illusion have significant impact on this world. The stock market and housing market have been proved to suffer from money illusion. Even though it influences just every individual's small decisions, the entire market will still suffer from it after all. On the other hand, the illusion about the perception of currency also has significant impact on the consumer market. Especially for some European countries, after the implementation of the euro, their people are all suffer from euro illusion which has been lasting for years.

However, although there have been significant amount of fields regarding money illusion being studied, I think there are still some other area worth being studied. For example, the review of literature has shown that little about how money illusion affects on Internet shopping. With the progress of Internet technology, consumers can purchase products from foreign countries without visiting those places in person. It will be very interesting to see how money illusion influences those consumers' behaviors.

On the other hand, since Euro illusion is prevailing in many European countries, research has been done to some extent. Nevertheless, there are two major limitations in the current research stream. First, most of focuses so far have been mainly on consumer behaviors and price perceptions. Not much research in marketing strategies is addressed. However, since research has shown that both of consumer behaviors and customers' price perceptions are significantly affected by money illusion, there are needs for multinational companies to figure out how they respond to these effects in terms of marketing strategies.

Secondly, under the research steam of Euro illusion, Italy and Ireland are two main countries that have been studied overwhelmingly because Italian Lire and Irish Pounds are most and least affected by the currency changeover, respectively. Therefore, most of focuses have been in these two countries and lots of comparisons have been done between them. However, since I have mentioned that national culture may play an important role in the changeover process, it will be interesting to see how consumers in other European countries respond to the Euro illusion.

\section{REFERENCES}

Anttila, M. (2004). Pricing Strategy and Practice: Consumer Price Perceptions after Translation to Euro Currency. Journal of Product and Brand Management, 13(1), 47-55.

Brett, J.M. (2000). Culture and Negotiation. International Journal of Psychology, 35(2), 97-104.

Brunnermeier, M.K., \& Jullard, C. (2008). Money Illusion and Housing Frenzies. The Review of Financial Studies, 21(1), 136-180.

Bryan, M.F., \& Gavin, W.T. (1994). A Different Kind of Money Illusion: The Case of Long and Variable Lags. Journal of Policy Modeling, 16(5), 529-540.

Cannon, E., \& Cipriani, G.P. (2006). Euro-Illusion: A Natural Experiment. Journal of Money, Credit, and Banking, 38(5), 1391-1403. 
Clark, T. (1990). International Marketing and National Character: A Culture-Free Dimensions of Culture. Journal of Cross-Culture Psychology, 18, 143-164.

Cohen, R.B., Polk, C., \& Vuolteenaho, T. (2005). Money Illusion in the Stock Market: The ModiglianiCohn Hypothesis. The Quarterly Journal of Economics, 120(2), 639-668.

Desmet, P. (2002). A Study of the Potential Effects of the Conversion to Euro. Journal of Product \& Brand Management, 11(3), 134-44.

Dusansky, R., \& Kalman, P.J. (1974). The Foundations of Money Illusion in a Neoclassical MicroMonetary Model. The American Economic Review, 64(1), 115-122.

Fair, R.C. (1971). Labor Force Participation, Wage Rates, and Money Illusion. Journal of Economics \& Statistics, 53(2), 164-168.

Fehr, E., \& Tyran J.R. (2001). Does Money Illusion Matter? The American Economic Review, 91(5), $1239-1262$.

Fehr, E., \& Tyran, J.R. (2005). Individual Irrationality and Aggregate Outcomes. Journal of Economic Perspectives, 19(4), 43-66.

Fisher, I. (1928). The Money Illusion. Published by New York Adelphi.

Gamble, A. (2007). The "Euro Illusion": Illusion or Fact? Journal of Consumer Policy, 30(4), 323-336.

Hofstede, G. (1980). Culture's Consequences: International Differences in Work-Related Value. London: Sage.

Hofstede, G. (1984). Cultural Dimensions in Management and Planning. Asia Pacific Journal of Management, pp. 81-99.

Hofstede, G. (2001). Culture's Consequences. Newbury Park, CA: Sage Publications.

Howitt, P. (1987). Money Illusion. New Palgrave Dictionary of Economics, 3, 518-519.

Kane, E.J., \& Klevorick, A.K. (1967). Absence of Money Illusion: A Sine Qua Non for Neutral Money? Journal of Finance, 22(3), 419-423.

Katsimbris, G.M., \& Miller, S.M. (1982). Money Illusion, Distribution Effects and the Household and Business Demands for Money. Journal of Banking and Finance, 6, 215-231.

Kluckhohn, C. (1951). The Study of Culture. In D. Lerner \& H.D. Lasswell (Eds.), The Policy Science (pp. 86-101). Stanford, CA: Stanford University Press.

Kooreman, P., Faber, R.P., \& Hofmans, H.M. (2004). Charity Donations and the Euro Introduction: Some Quasi-Experimental Evidence on Money Illusion. Journal of Money, Credit, and Banking, 36(6), 1121-1124.

Larsen, J.E. (1989). Money Illusion and Residential Real Estate Transfer. The Journal of Real Estate Research, 4(1), 13-19.

Marques, J.F. (1999). Changing "EUROpe" - The Euro as A New Subject for Psychological Research in Numerical Cognition. European Psychologist, 4, 152-156.

Missier, F.D., Bonini, N., \& Ranyard, R. (2007). The Euro Illusion in Consumers' Price Estimation: An Italian-Irish Comparison in the Third Year of the Euro. Journal of Consumer Policy, 30(4), 337354.

Monroe, K.B. (1990). Pricing: Making Profitable Decisions (2nd ed.). McGraw-Hill, New York, NY.

Murphy, J.C., \& Das, S.K. (1976). Money Illusion and Balance-of-Payments Adjustment. Journal of Political Economy, 84(1), 73-82.

Mussweiler, T., \& Strack, F. (2004). The Euro in the Common European Market: A Single Currency Increases the Comparability of Prices. Journal of Economic Psychology, 25, 557-563.

Przybyszewski, K., \& Tyszka, T. (2007). Emotional Factors in Currency Perception. Journal of Consumer Policy, 30(4), 355-365.

Rothschild, K.W. (1965). Illusions about Money Illusion? Journal of Political Economy, 73(3), 298-299.

Shafir, E., Diamond, P., \& Tversky, A. (1997). Money Illusion. The Quarterly Journal of Economics, 112(2), 341-374.

Smithies, A. (1942). The Behavior of Money National Income under Inflationary Conditions. Quarterly Journal of Economics, 57(1), 113-128. 
Tyszka, T., \& Przybyszewski, K. (2006). Cognitive and Emotional Factors Affecting Currency Perception. Journal of Economic Psychology, 27, 518-530.

Wertenbroth, K., Soman, D., \& Chattopadhyay, A. (2007). On the Perceived Value of Money: The Reference Dependence of Currency Numerosity Effects. Journal of Consumer Research, 34(1), $1-10$.

Zollinger, M. (2002). In search of a conceptual framework for monetary bilingualism: The contribution of psycholinguistic models. Proceedings of the 2002 Fordham University Behavioral Pricing Conference (Vol. 2002, pp.17-24). New York, NY. 